INESC-ID Lisboa, Portugal \& Linguateca \& University of Oslo, Norway

\title{
Paraphrasing Emotions in Portuguese
}

\author{
Cristina Mota \\ cmota@ist.utl.pt \\ Diana Santos \\ d.s.m.santos@ilos.uio.no \\ Anabela Barreiro \\ anabela.barreiro@inesc-id.pt
}

NooJ conference, 5-7 June 2020

This work was supported by Portuguese national funds through FCT, Fundação para a

Ciência e a Tecnologia, under project UIDB/50021/2020

\section{Presentation}

Introduction

Two projects cooperate

Emotions in language

Paraphrasing with eSPERTo

An empirical study

Procedure

The material

Quantitative data

First results

Encoding in NooJ

Future work 


\section{Two projects}

Emocionário An attempt to organize emotions in Portuguese and annotate them in corpora

- Mota \& Santos (2015), Ramos et al. (2020), http://www.linguateca.pt/Emocionario/

\section{Two projects}

Emocionário An attempt to organize emotions in Portuguese and annotate them in corpora

- Mota \& Santos (2015), Ramos et al. (2020), http://www. linguateca.pt/Emocionario/

- eSPERTo A paraphrasing system using the NooJ linguistic engine, grammars, and lexicons

- Barreiro, 2010; Mota et al., 2016; Barreiro et al., 2020 https://esperto.hlt.inesc-id.pt/esperto/esperto/demo.pl 


\section{Collaboration}

Together, we might

- use the paraphrasing system for emotions

- use the emotions in the paraphrasing system

- evaluate the emotion classification so far

- identify interesting issues in the paraphrasing of emotions

- measure how many emotion paraphrases one can get from parallel text (currently, in two varieties of Portuguese)

\section{Emocionário in a nutshell}

Emocionário, a subproject of Linguateca, has as aims

- marking all references to emotion in text in our corpora (not expression of emotion!)

- classifying them in 24 not mutually-exclusive categories

- attempting to obtain guidelines both for emotion identifying and classifying

- getting a quantitative overview of emotions in Portuguese texts

- making the emotion annotation publicly available in the AC/DC corpora 


\section{Emotion overview}

More than 4,000 lemmas divided in 24 categories

Not yet revised. Data from literary texts in October 2019.

\section{Approximate translations}

\begin{tabular}{c|c|l|c|} 
love & 107,203 & desire & 72,242 \\
happiness & 61,541 & unhappiness & 61,488 \\
fear & 38,473 & generic & 30,237 \\
shame & 28,135 & pride & 25,439 \\
courage & 21,117 & surprise & 20,637 \\
humility & 20,282 & hate & 19,502 \\
hope & 19,259 & anger & 14,943 \\
satisfaction & 14,651 & despair & 14,601 \\
longing & 13,037 & admiration & 9,341 \\
sorrow & 9,288 & relief & 9,020 \\
gratitude & 7,190 & envy & 4,652 \\
ungratitude & 2,295 & insatisfaction & 2,233
\end{tabular}

\section{Examples of emotions}

the pride group

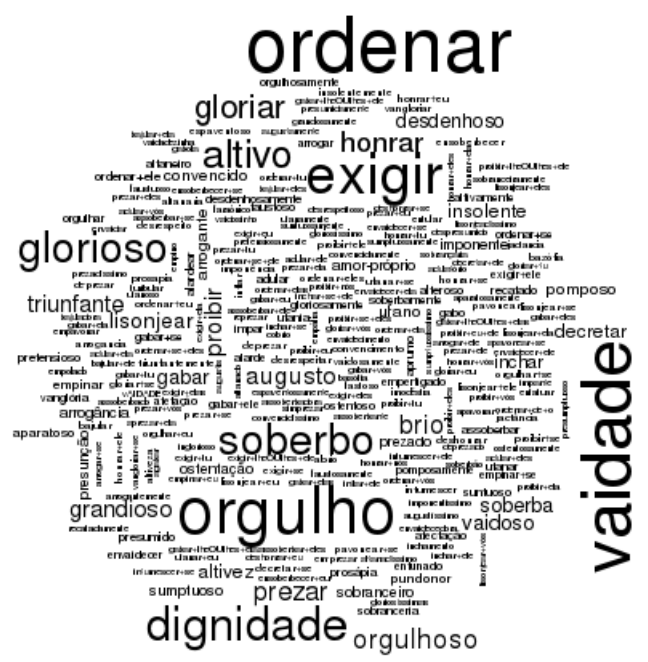

the shame group

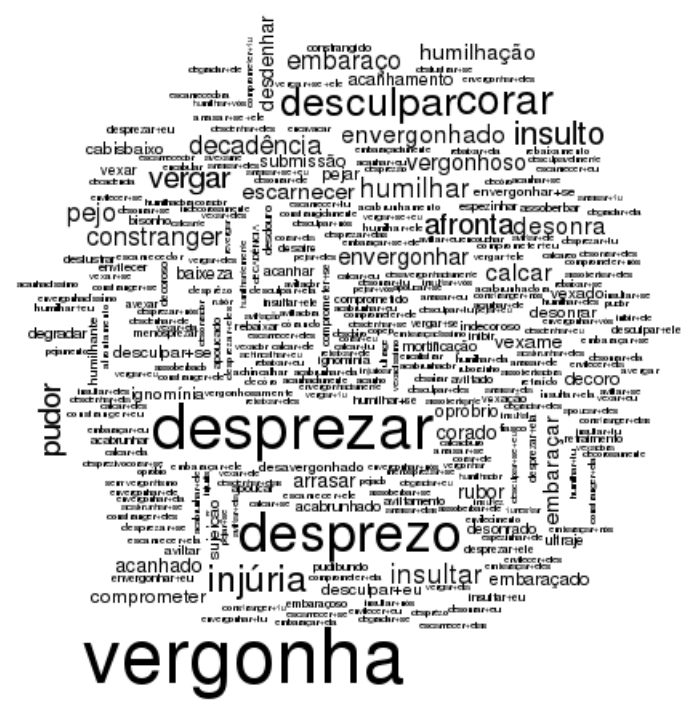




\section{eSPERTo in a nutshell}

development and improvement of a paraphrasing system using linguistically enhanced resources developed within NooJ

- provide suggestions of semantically identical expressions for text (re)writing

- access to paraphrastic units that contribute to the linguistic and stylistic quality improvement of a text

- language understanding when the use of certain expressions are unknown or unclear in an input text

- show how vocabulary words are used when included in multiword expressions, thus significantly extending the usefulness of a simple dictionary

- integration of paraphrastic technology into other applications to make editing seamless

\section{Uses of ESPERTo}

- eSPERTo's paraphrases have been tested in distinct scenarios

- in a machine translation application [Barreiro, 2009]

- in a dialogue system, to increase the linguistic knowledge of an intelligent virtual agent [Mota et al. 2016]

- in a summarization and simplification system [Mota et al. 2016]

- in a study of the differences in Portuguese varieties in literary texts [Barreiro and Mota 2018] [Rebelo and Barreiro 2018] [Barreiro et al., 2020]

- in conversion of informal into formal language and vice-versa [Barreiro et al. 2018]

- in transformation of technical versus non-expert expressions

- in the editorial process [Barreiro et al., 2020] 


\section{The linguistic resources used in eSPERTo}

Efforts have been undertaken to integrate and improve linguistic resources available for Portuguese, which were dispersed and lacked organic articulation among them; e.g. use of lexicon-grammar tables:

- paraphrases of human intransitive adjectives (HIA) [Mota et al. 2015]

- paraphrases of support verb constructions (SVC) with fazer [Mota et al., 2017]

- paraphrases of support verb constructions (SVC) with ser de [Mota et al, 2018]

\section{Paraphrases of HIA and SVC with fazer and ser de}

\section{eSPERTo - System for Paraphrasing in Editing and Revision of Text}

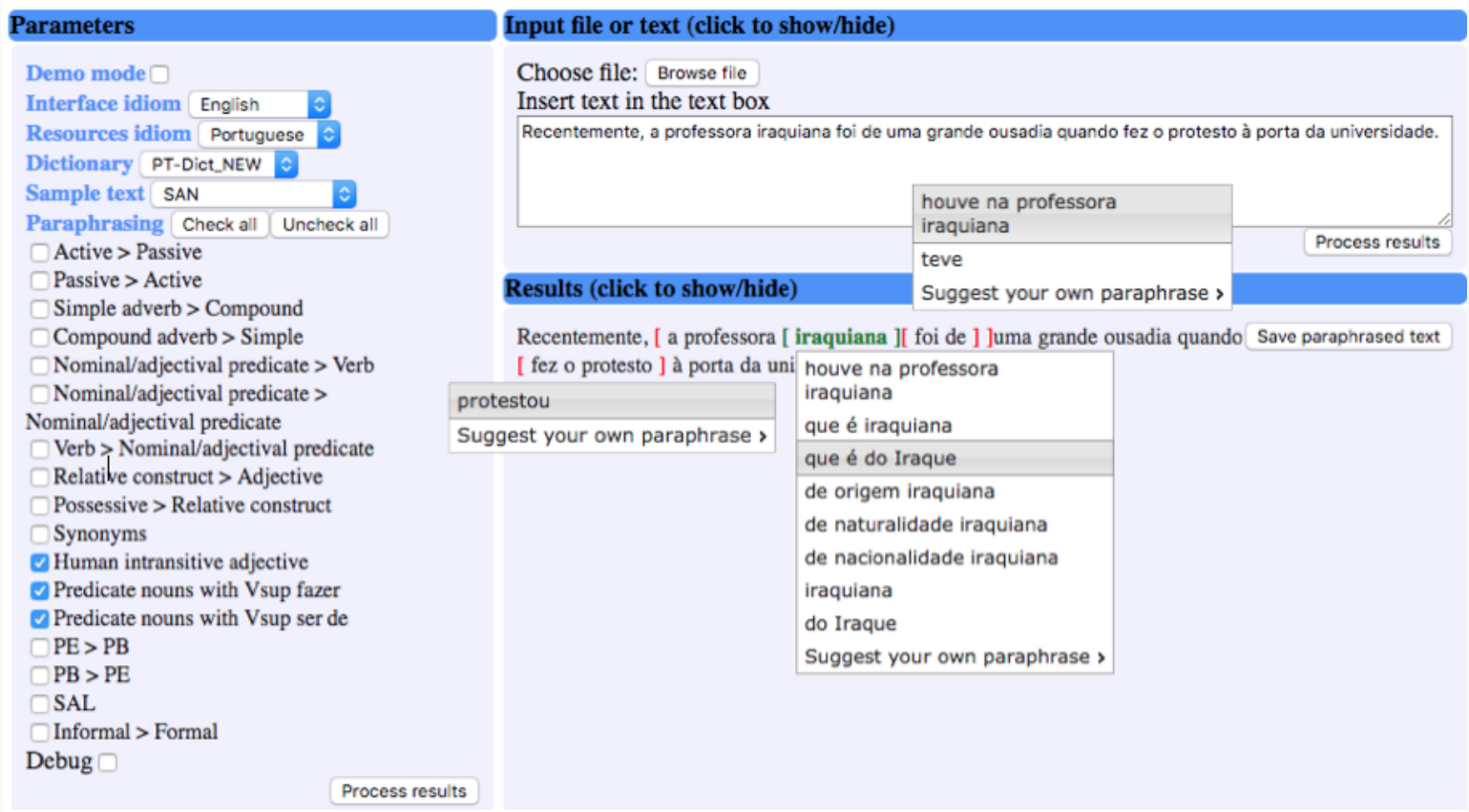




\section{Procedure}

The collaboration seemed to require at least the following steps

- automatically annotate parallel text with emotions

- revise it (to guarantee correctness and to assess the quality of the automatic annotation)

- identify cases where emotions had been maintained but with other words, and cases where different emotions had been chosen

- code them as paraphrastic resources

Also, identify whether the emotion groups could be used as sources of more paraphrases.

\section{Data}

We had five different texts in two varieties of Portuguese (from Portugal and from Brazil), already sentence aligned in previous projects:

1. the independent translation of two works by David Lodge into the two varieties: Therapy (DL1) and Changing Places (DL3)

2. the independent translation of one work by Jostein Gaarder into the two varieties: Hallo? Er det noen der? (JG)

3. the independent translation of one work by Karl Ove Knausgaard into the two varieties: Min Kamp 1 (КОК)

4. the adaptation of a book by Afonso Cruz, a Portuguese author, into Brazilian Portuguese: Os livros que devoraram o meu pai (AC)

Except for the last work, we only had excerpts. 


\section{Some numbers}

alu = alignment units; rev. emo = number of emotions after human revision

\begin{tabular}{|c|c|c|c|c|c|c|}
\hline text & words & alu & alu emo & emo & alu emo & rev. emo \\
\hline $\mathrm{AC}_{P P}$ & 19,214 & 1261 & 225 & 264 & 276 & 338 \\
\hline$A C_{P B}$ & 19,127 & & 234 & 272 & 281 & 349 \\
\hline DL1 $1_{P P}$ & 17,422 & 652 & 221 & 290 & 271 & 391 \\
\hline $\mathrm{DL} 1_{P B}$ & 17363 & & 214 & 285 & 272 & 393 \\
\hline DL3PP & 11,133 & 417 & 139 & 203 & 158 & 267 \\
\hline DL3PB & 11,735 & & 123 & 179 & 162 & 273 \\
\hline$J G_{P P}$ & 4,337 & 222 & 72 & 97 & 84 & 127 \\
\hline$J G_{P B}$ & 4,320 & & 69 & 102 & 79 & 133 \\
\hline $\mathrm{KOK}_{P P}$ & 7,212 & 310 & 58 & 84 & 68 & 111 \\
\hline $\mathrm{KOK}_{P B}$ & 7,146 & & 60 & 86 & 71 & 117 \\
\hline Total $_{P P}$ & 59,578 & 2862 & 715 & 938 & 857 & 1234 \\
\hline Total $_{P B}$ & 59,988 & & 700 & 924 & 865 & 1265 \\
\hline
\end{tabular}

\section{Emotions per alignment unit}

"Alignment unit" is what corresponds to one sentence in the original.

For the alignment units featuring at least one emotion:

$\begin{array}{lr}\text { Difference in number of emotions } & \text { number of alu } \\ 0 & 627 \\ 1 & 222 \\ -1 & 77 \\ 2 & 8 \\ -2 & 5 \\ -3 & 2 \\ 3 & 1\end{array}$

there are 334 cases (out of 2862, thus $12 \%$ ) where one translator referred to an emotion and the other did not!

Of the 627 alignment units with the same number of emotions, 596 had exactly the same groups of emotions, corresponding to 809 cases. In 280 al. units the emotion words were not the same. 


\section{Findings}

A good source of inspiration for paraphrasing, after careful scrutiny.

- Surprisingly frequent addition or removal of emotions in the alignment units

- Fairly frequent change of emotion group

\section{Examples}

PP - só teria confirmado os seus profundos receios

$P B$ - apenas confirmado suas suspeitas mais profundas

$E N$ - merely confirmed his deepest misgivings

- Frequent change of the word used for the same group of emotions)

\section{Examples}

$P P$ - isso não teria surpreendido $M Z$ por aí além

$P B$ - isto não teria causado nenhuma surpresa $a \mathrm{MZ}$

$E N$ - it would not have surprised MZ unduly

\section{Multiword-level emotion}

- We used Emocionário to annotate emotion at the word level, since it uses a dependency formalism

- But often emotions are expressed as multiwords and this had to be annotated manually

\section{Examples}

PP - Ela fez beicinho e disse: - É que eu tenho uma ideia fabulosa para uma série muito original, uma espécie de versão inglesa do Twin Peaks. $P B$ - Ela fez um beicinho e disse: - O negócio é que tive uma idéia sensacional para uma novela diferente, tipo Twin Peaks inglesa. EN - She pouted a little and said, "It's just that I have this fabulous idea for an offbeat soap, a kind of English Twin Peaks.

"fazer beicinho" (EN: pout, pouting) is a MWU that expresses emotion of sadness, disappointment, disagreement. 


\section{Multiword-level emotion}

\section{Examples}

PP - Arranquei a venda e pus-me aos saltos na sala, a rogar tantas pragas $e$ a dizer tantos palavrões que acabei por ficar chocado e me calei.

$P B$ - Arranquei a venda dos olhos e pulei de um lado para o outro ao redor da sala , xingando e blasfemando coisas tão terríveis que finalmente minha vociferação me fez silenciar

$\mathrm{EN}$ - I tore off the blindfold and hopped round the room cursing and blaspheming so terribly I finally shocked myself into silence.

In Portuguese, the expressions "rogar [] pragas" and "dizer [] palavrões" are MWU that express emotion of anger, rage, fury.

\section{Aligning MWU-level emotions with CLUE-Aligner}

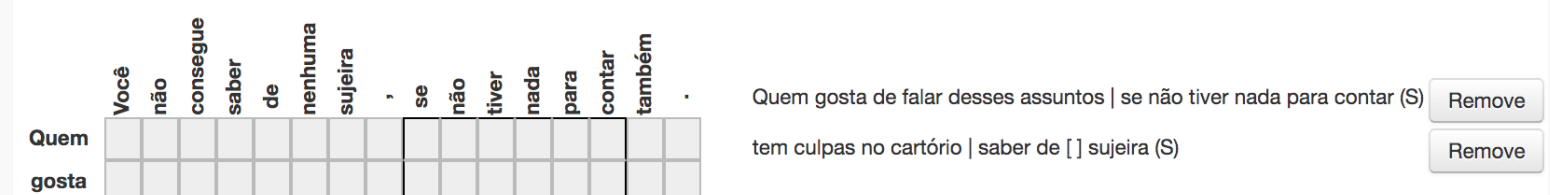




\section{Aligning MWU-level emotions with CLUE-Aligner}

Browse Source Corpus

Browse Target Corpus

Browse Alignments

Help About CLUE-Aligner

Load Corpora $5 \varepsilon \vee$ Save Alignments

Export Alignments

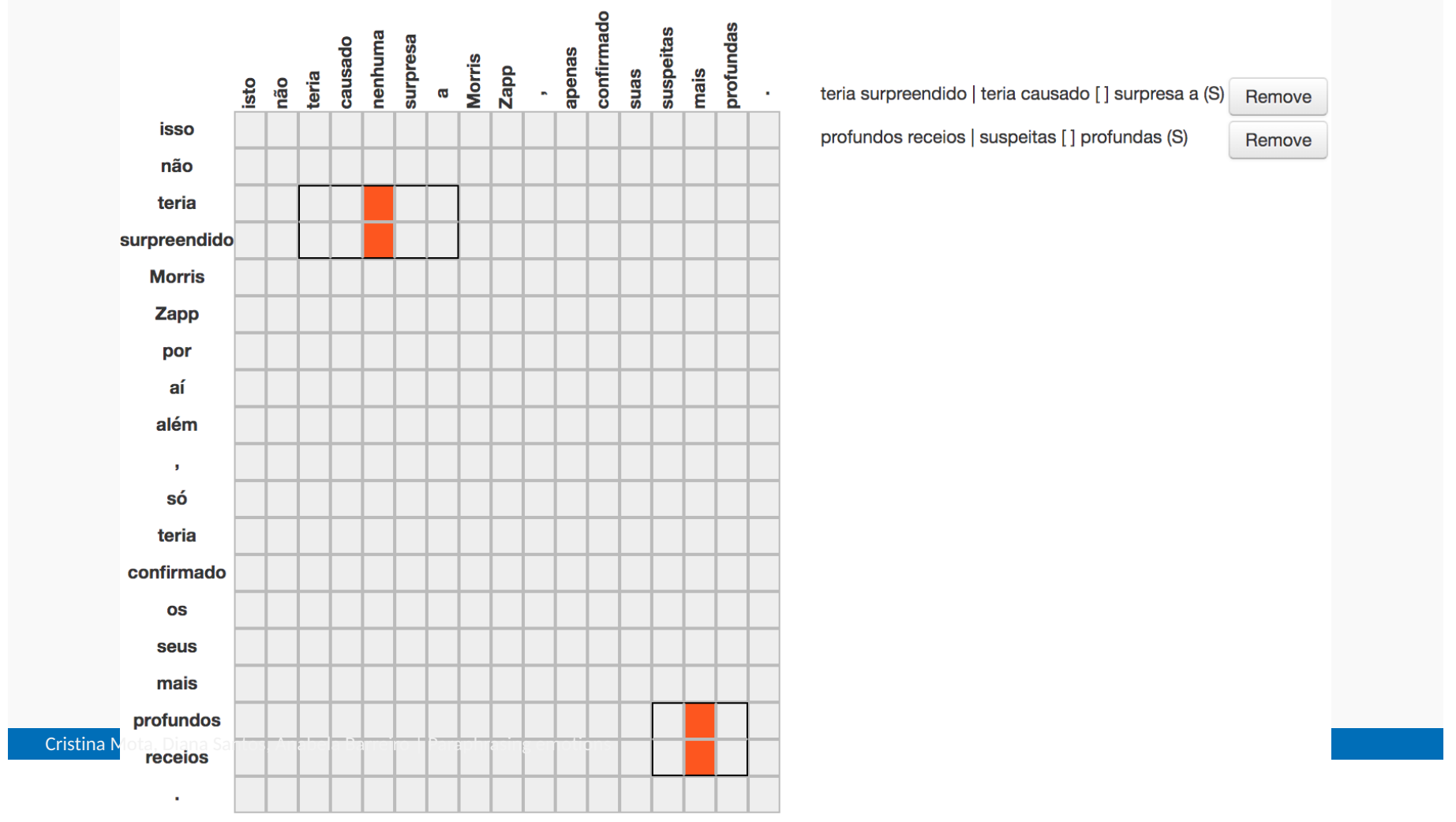

\section{How to include emotion paraphrases in NooJ}

NooJ resources and grammars underlie eSPERTo

Examples that could be encoded

- falta de $+\mathrm{N}(+$ Abstract $)=$ não ter $\mathrm{N}(+\mathrm{Abstract})$ sentir falta de $\mathrm{N}(+$ Human) = ter saudade(s) de $\mathrm{N}(+$ Human)

- com um sorriso $A D J($ nervoso) = sorrindo $A D V$ (nervosamente)

- $\mathrm{N}$ related to body parts or actions: sorriso (smile), riso (laugh), olhos (eyes) choro (cry), ombros (shoulders - shrug), sobrolho (eyebrows frown), capitalizing from Esqueleto [Freitas et al. 2015]

- opposite polarity emotions - sorriso (+) triste (-) (sad smile); lastimável (-) sorte (+) (unfortunate luck)

- (Due to Corona problems, we were not yet able to encode the grammars in NooJ, but this will be done as soon as possible) 


\section{Future work}

Analysis of MWU expressing emotion in large corpora (AC/DC)

- Design and construction of high coverage paraphrastic grammars in NooJ for emotion-related multiwords and other phrases expressing emotion, such as

- emotion-conveying idiomatic expressions, which may correspond to a single word with identical meaning, e.g. ter pena de (have pity for), sentir falta de (miss), encolher os ombros (shrug shoulders), fazer beicinho (pout), (falar) com o coração nas mãos (heart in [] hands), de cabelos em pé (hair raising)

- emotion quantification, e.g. gostar muito, paraphrase of amar (like a lot = love); não gostar nada, paraphrase of detestar (do not like at all = hate), also using opposite emotions

- combination of different emotions, e.g. sorriso triste (sad smile); má sorte (bad luck).

- Evaluation of emotional paraphrases with users

Thank you for your attention! 